\section{Exposure with Far-red Radiation for Control of Oedema Injury on 'Yale' Ivy Geranium}

\author{
Anusuya Rangarajan'and Theodore W. Tibbitts ${ }^{2}$ \\ Department of Horticulture, University of Wisconsin, Madison, WI 53706
}

Additional index words. Pelargonium peltatum, physiological disorder, intumescence injury, galls, controlled environments

\begin{abstract}
Oedema, a physiological disorder, affects several cultivars of ivy geranium [Pelargonium peltatum (L.) L 'Hér. ex Ait) when grown in greenhouses. This study investigated the regulation of oedema on this crop using far-red radiation because these wavelengths inhibited the injury on Solanaceous sp. Plants were exposed to far-red radiation from Sylvania \#232 far-red lamps on abaxial and adaxial surfaces of leaves. A far-red photon flux of 15 to $20 \mu \mathrm{mol} \cdot \mathrm{m}^{-2} \cdot \mathrm{s}^{-1}(700-S 00 \mathrm{~nm})$ was not effective in preventing oedema injury. A far-red abaxial treatment during the light period tended to reduce the amount of injury that developed when photosynthetic photon flux was low (130-170 $\mu \mathrm{mol} \cdot \mathrm{m}^{-2} \cdot \mathrm{s}^{-1}$ ), but this inhibition of the injury was absent with higher photon flux. The results from these studies indicate the use of supplemental far-red radiation treatments in greenhouses would not be justified because adequate and consistent control of the injury on ivy geraniums was not achieved.
\end{abstract}

Throughout its cultivated history, Pelargonium peltatum has been affected by the physiological disorder oedema, or intumescence injury. This disorder is described as physiological because no pathogens are associated with injury. Injury is generally visible as 1- to 3-mm blisters or galls on lower surfaces of recently matured leaves. As severely affected leaves age, they may become chlorotic and necrotic, and abscise. Death of leaf tissue decreases aesthetic and economic value of this crop.

The predominant explanation for injury has been that it occurs under conditions of high relative humidity $(\mathrm{RH})$, high soil moisture, and cool weather, which lead to an excess of water in leaf tissues and gall development (Metwally et al., 1971). Recent work investigating intumescence injury on Solanaceous $\mathrm{sp}$. found that the disorder is controlled by the phytochrome system (Morrow and Tibbitts, 1988). Red radiation $(600-700 \mathrm{~nm})$ was required for injury to occur, and far-red radiation (700-800 nm) prevented injury development. Based on this report, the following experiments were undertaken to establish whether use of a supplementary far-red radiation treat-

Received for publication 28 Dec. 1992. Accepted for publication 12 July 1993. This research was supported bya grantfromtheGloecknerFoundation and by the College f Agriculture and Life Sciences, Univ. of Wisconsin-Madison. Appreciation is extended to Olgevee Associates for the donation of plant material.The costof publishing this aper was defrayed in part by the payment of page charges. Under postal regulations, this paper therefore must be hereby marked advertisement solely to indicate this fact.

${ }^{1}$ Former Graduate Research Assistant.Present address: Dept. of Horticulture, Michigan State Univ., East Lansing, MI 48824.

${ }^{2}$ Professor. ment in the growing environment would protect ivy geraniums from oedema.

A far-red exposure was applied to the abaxial side of leaves in most studies because injury develops primarily on this surface of ivy geranium leaves (Balge et al., 1969). This exposure method allowed for treatment of separate plants with different far-red levels within a single growth chamber. For undersurface exposures, lamp boxes were constructed of opaque gray polyvinyl chloride with no top or bottom. These boxes housed lamp fixtures for fat--red radiation treatments and were covered with a sheet of transparent acrylic plastic that absorbed ultraviolet (UV) radiation emitted by lamps. Ultraviolet radiation has been shown to inhibit oedema injury on other species (Morrow and Tibbitts, 1988). Control plants did not receive supplementary radiation to the lower surface of leaves.

The far-red radiation treatments were provided with 50-cm Sylvania \#232 far-red fluorescent lamps. To remove emissions in the blue and red wavelengths, lamps were wrapped with colored cellophane filters. A low level of far-red photons, $2.8 \mu \mathrm{mol} \cdot \mathrm{m}^{-2} \cdot \mathrm{s}^{-1}(700-800$. rim), was obtained with a Roscolux \#27 darkred filter (Musson Theatrical, Santa Clara, Calif.). A high level of far-red photons, 4.3 $\mu \mathrm{mol} \cdot \mathrm{m}^{-2} \cdot \mathrm{s}^{-1}(700-800 \mathrm{rim})$, was obtained by wrapping lamps with a 0.4 -mm-thick red acetate filter material (Trancil Wrap, North Lake, Ill.). The spectrum provided by these far-red treatment lamps (Fig. 1) was determined with a spectroradiometer (model 550/551; EG\&G, Salem, Mass.).

The chamber lighting was provided by an overhead bank of cool-white fluorescent lamps. A layer of polyethylene plastic was installed immediately beneath chamber lamps to remove UV radiation emitted by them. Photosynthetic photon flux (PPF) within the chamber was measured with a LI-COR 185 quan- tum meter (LI-COR, Lincoln, Neb.) and adjusted to the desired level by installing layers of cheesecloth below the light bank.

'Yale' ivy geranium was used because of its high susceptibility to oedema injury. Rooted cuttings were received from Olgevee Associates (Connellsville, $\mathrm{Pa}$.), potted into 0.5-liter plastic pots using a 50 peat :50 vermiculite $(\mathrm{v} / \mathrm{v})$ medium, and grown at an it-radiance level of $160 \mu \mathrm{mol} \cdot \mathrm{m}^{-2} \cdot \mathrm{s}^{-1} \mathrm{PPF}$, at $2212 \mathrm{C}$, and $70 \% \pm 4 \% \mathrm{RH}$. After 3 weeks of growth, plants of similar appearance with stems $>20 \mathrm{~cm}$ long were selected and transplanted into rectangular plastic containers, $60 \times 15 \times 20 \mathrm{~cm}$ (length, width, depth), with a 50 peat :50 vermiculite $(\mathrm{v} / \mathrm{v})$ potting medium. Two or three plants were transplanted into each container. All flowers and sideshoots were removed at transplanting and throughout the experiment, limiting growth to a single stem. As plant stems elongated, they were positioned horizontally over the selected lamp boxes for treatment and maintained using twist ties hooped over stems and secured to box covers. A modified halfstrength nutrient solution (Hammer et al., 1978) was applied four times daily to excess, to each plant container using an automatic drip tube watering system. Plants were grown for 1 week after transplanting. Radiation treatments were then initiated.

The first experiment was conducted to determine if abaxial treatments with far-red radiation would prevent injury. Two plant containers with two plants in each were placed within the chamber. One plant from each container was positioned over a lamp box and received a far-red treatment of $2.8 \mu \mathrm{mol} \cdot \mathrm{m}^{-2} . \mathrm{s}^{-1}$ for the duration of the light period and the other plant was positioned over an empty lamp box and received no abaxial radiation. The over-head cool-white PPF level, measured at the surface of the boxes, was $130 \pm 15$ $\mu \mathrm{mol} \cdot \mathrm{m}^{-2} \mathrm{~s}^{-1}$ fora 16 -h light period. The chamber was maintained at $18 \pm 2 \mathrm{C}$ and $70 \% \pm 4 \%$ $\mathrm{RH}$ over the light and dark period. Experiment duration was 6 weeks.

In a second experiment, two levels of farred radiation were investigated with a chamber PPF of $165 \pm 15 \mu \mathrm{mol} \cdot \mathrm{m}^{-2} \cdot \mathrm{s}^{-1}$, a level $27 \%$ higher than that supplied in the first experiment. Three containers, each holding three plants, were prepared for the study. One plant was positioned over a far-red photon flux of $2.8 \mu \mathrm{mol} \cdot \mathrm{m}^{-2} \cdot \mathrm{s}^{-1}$, the second over far-red of 4.3 $\mu \mathrm{mol} \cdot \mathrm{m}^{-2} \cdot \mathrm{s}^{-1}$, and the third over an empty lamp box. Temperature, $\mathrm{RH}$, and duration of the light period were maintained at the levels used for the first experiment. Experiment duration was 6 weeks.

A third experiment investigated the use of far-red radiation treatment at $2.8 \mu \mathrm{mol} \cdot \mathrm{m}^{-2} \cdot \mathrm{s}^{-1}$ with an elevated chamber PPF of 230 $\mu \mathrm{mol} \cdot \mathrm{m}^{-2} \cdot \mathrm{s}^{-1}$. This chamber irradiance level was the highest used in the abaxial exposure studies. Three containers, each with two plants, were prepared for this study. One plant received abaxial far-red treatment and one plant received no abaxial treatment. Temperature, $\mathrm{RH}$, and duration of light period were maintained at the levels used for the first experiment. Experiment duration was 6 weeks. 


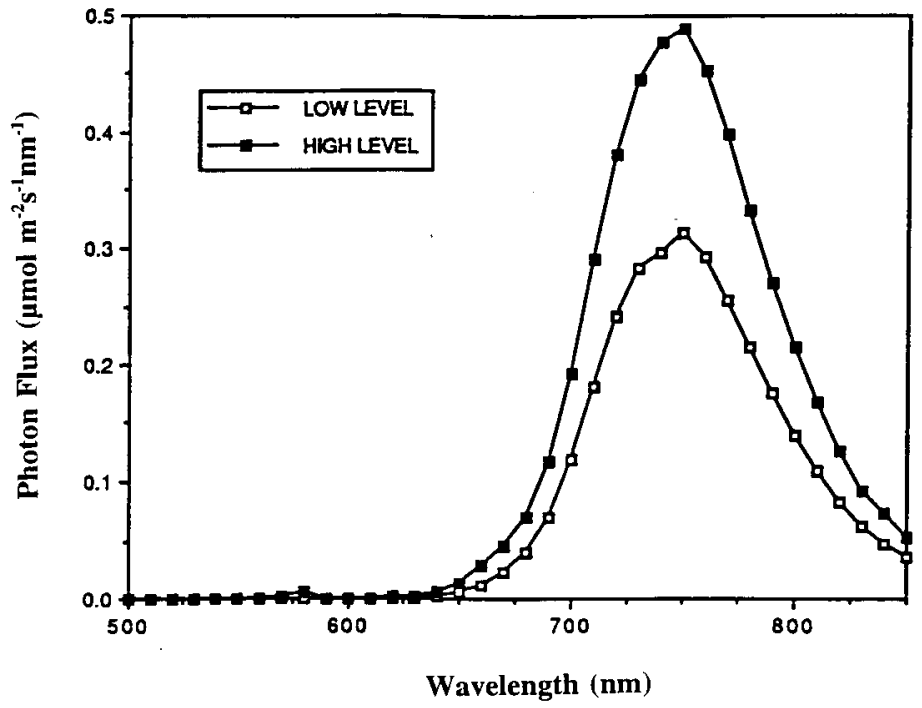

Spectra of low and high far-red photon flux used in abaxial leaf irradiation studies.

The use of a far-red radiation treatment at the end of the light period was investigated in a final study. A far-red fluorescent bulb wrapped with Roscolux \#27 cellophane was used to supply the treatment. A 48-cm-long fluorescent fixture was hung over plants to provide treatment to the upper surfaces of leaves. This lamp was $45 \mathrm{~cm}$ above plants and supplied a far-red photon flux of $4.2 \mu \mathrm{mol} \cdot \mathrm{m}^{-2} \cdot \mathrm{s}^{-1}$. Farred treatment was applied for $15 \mathrm{~min}$, beginning 5 min after the start of the dark period.

Plants were grown from cuttings in 0.5liter plastic pots, as described previously. Sixteen plants were selected for the experiment based on uniformity of stem length and size of youngest leaf pair. Eight treatment plants were arranged, four on each side of the far-red fixture. Eight control plants, which received no far-red radiation, were placed next to the treatment plants, farther from the far-red source. A black cloth barrier was suspended between control plants and treated plants at the start of each dark period, so essentially no far-red radiation reached control plants. This screen was removed at the end of each dark period to minimize any temperature and light differences during the light period. Overhead PPF from cool-white fluorescent lamps was $390 \pm$ $8 \mu \mathrm{mol} \cdot \mathrm{m}^{-2} \cdot \mathrm{s}^{-1} \mathrm{PPF}$, providing a $12-\mathrm{h}$ light period. No UV-absorbing barrier existed in this chamber, which was maintained at $23 \pm$ $3 \mathrm{C}$ and $70 \% \pm 4 \% \mathrm{RH}$. Experiment duration was 4 weeks.

In the first three experiments, plants were harvested by cutting stems at soil level. Differences in whole-plant appearances were recorded. Each node generally had two leaves, and leaf diameter was measured at the widest part of each blade. The node closest to the growing point with leaf diameters $>3.0 \mathrm{~cm}$ was denoted as node one. Leaves from the fourth and fifth nodes were evaluated for oedema by laying a transparent grid marked with $0.25-\mathrm{cm}^{2}$ squares over a leaf and counting the number of grid squares containing galls. The total number of squares encompassing the leaf surface was recorded also. The percentage of squares containing oedema was then calcu-
Far-red treatments during the light period (Expts. 1-3) were not effective in preventing gall formation (Table 1). With PPF of 130 and $165 \mu \mathrm{mol} \cdot \mathrm{m}^{-2} \cdot \mathrm{s}^{-1}$, there was some reduction in gall formation relative to the control, but differences were not significant. No reduction in oedema occurred with the highest level of farred.

Far-red treatments during the light period tended to induce leaves to grow larger, although not significantly so, than those on plants receiving no abaxial far-red exposure (Table 2). Although such differences were not statistically significant in anyone experiment, there was an increase in area with far-red treatments in all experiments. Some internodes were observed to be elongated; however, lengths were not recorded.

Treatment with far-red photons for $15 \mathrm{~min}$ at the start of the dark period increased, rather than decreased, the level of oedema that developed on plants (Table 3). This far-red treatment, when applied at the beginning of the dark period, doubled the number of galls on evaluated leaves. Internodes of plants receiving end-of-day treatments were elongated, averaging $11.7 \mathrm{~cm}$, compared to controls, which averaged $7.7 \mathrm{~cm}$. Leaf areas were slightly larger in far-red-treated plants than in control plants (Table 3).

The effect of supplemental far-red treatments appeared to interact with chamber PPF, although the individual or interacting effects were not significant. Under PPF $<170$ $\mu \mathrm{mol} \cdot \mathrm{m}^{-2} \cdot \mathrm{s}^{-1}$, addition of far-red photons appeared to cause some decrease in oedema formation. Stems elongated more in treated than in control plants, although lengths were not recorded. Stem elongation is known to result from enhanced far-red flux on many species (Holmes and Smith, 1977), indicating that plants perceived supplemental far-redtreatments. However, when chamber PPF exceeded $170 \mu \mathrm{mol} \cdot \mathrm{m}^{-2} \cdot \mathrm{s}^{-1}$, far-red treatment had no effect on treated plants, and no difference in stem elongation was observed in our experi-
$-800 \mathrm{~nm}$ ) during the light period on oedema Table 1. Effect of far-red photon flux $(700-800 \mathrm{~nm})$ during the light period
injury of plants grown at three photosynthetic photon flux levels.

\begin{tabular}{lccc}
\hline \hline $\begin{array}{l}\text { Far-red flux } \\
\left(\mu \mathrm{mol} \cdot \mathrm{m}^{-2} \cdot \mathrm{s}^{-1}\right)\end{array}$ & \multicolumn{3}{c}{ Photosynthetic photon flux $\left(\mu \mathrm{mol} \cdot \mathrm{m}^{-2} \cdot \mathrm{s}^{-1}\right)$} \\
\cline { 2 - 4 } & 130 & 165 & 230 \\
\hline & & Leaf area injured $(\%)$ & \\
2.8 & $8.6 \pm 5.3$ & $49.3 \pm 15.1$ & $15.7 \pm 8.9$ \\
4.3 & $3.8 \pm 3.4^{\mathrm{Ns}}$ & $31.6 \pm 7.1^{\mathrm{Ns}}$ & --- \\
\hline
\end{tabular}

${ }^{z}$ Average $\pm S D$ of eight leaves for plants at $130 \mu \mathrm{mol} \cdot \mathrm{m}^{-2} \cdot \mathrm{s}^{-1}$ and of 12 leaves for plants at 165 and $230 \mu \mathrm{mol} \cdot \mathrm{m}^{-2} \cdot \mathrm{s}^{-1}$.

${ }^{\text {Ns }}$ Leaf area injured not significantly different from control plants at $P \leq 0.05$.

Table 2. Effect of far-red photon flux $(700-800 \mathrm{~nm})$ during the light period on leaf area of plants grown at three photosynthetic photon flux levels.

\begin{tabular}{|c|c|c|c|}
\hline \multirow{2}{*}{$\begin{array}{l}\text { Far-red flux } \\
\left(\mu \mathrm{mol} \cdot \mathrm{m}^{-2} \cdot \mathrm{s}^{-1}\right)\end{array}$} & \multicolumn{3}{|c|}{ Photosynthetic photon flux $\left(\mu \mathrm{mol} \cdot \mathrm{m}^{-2} \cdot \mathrm{s}^{-1}\right)$} \\
\hline & 130 & 165 & 230 \\
\hline \multicolumn{4}{|c|}{ Leaf area ${ }^{\tau}\left(\mathrm{cm}^{2}\right)$} \\
\hline 0 & $68.7 \pm 11.4$ & $53.1 \pm 7.6$ & $74.9 \pm 7.2$ \\
\hline 2.8 & $76.6 \pm 7.6^{\mathrm{Ns}}$ & $75.8 \pm 9.4^{\mathrm{Ns}}$ & $78.3 \pm 4.6^{\mathrm{Ns}}$ \\
\hline 4.3 & & $65.8 \pm 3.1^{\mathrm{NS}}$ & \\
\hline
\end{tabular}

${ }^{\mathrm{z}}$ Average \pm sD of eight leaves for plants at $130 \mu \mathrm{mol} \cdot \mathrm{m}^{-2} \cdot \mathrm{s}^{-1}$ and of 12 leaves for plants at 165 and $230 \mu \mathrm{mol} \cdot \mathrm{m}^{-2} \cdot \mathrm{s}^{-1}$.

${ }^{\text {ss } L e a f ~ a r e a ~ n o t ~ s i g n i f i c a n t l y ~ d i f f e r e n t ~ f r o m ~ c o n t r o l ~ p l a n t s ~ a t ~} P \leq 0.05$. 
Table 3. Effect of far-red photon flux $\left(4.2 \mu \mathrm{mol} \cdot \mathrm{m}^{-2} \cdot \mathrm{s}^{-1}\right)$ supplied for $15 \mathrm{~min}$ at the beginning of the dark period on plant growth and oedema injury.

\begin{tabular}{lcr}
\hline \hline Variable & Far-red & \multicolumn{1}{c}{ No far-red } \\
\hline Leaf area $\left(\mathrm{cm}^{2}\right)^{\mathrm{x}}$ & $73.4 \pm 7.0^{*}$ & $60.1 \pm 8.7$ \\
${\text { Internode length }(\mathrm{cm})^{y}}$ & $11.7 \pm 1.7^{*}$ & $7.7 \pm 0.6$ \\
Number of galls $^{\mathrm{x}}$ & $37.6 \pm 17.0^{*}$ & $18.5 \pm 6.8$
\end{tabular}

${ }^{\mathrm{z}}$ Average of the four oldest leaves of eight plants \pm SD.

${ }^{y}$ Average length of three internodes of eight plants \pm so.

${ }^{x}$ Number of galls for $6.5-\mathrm{cm}^{2}$ area of leaf at point of petiole attachment.

"Significantly different from control plants at $P \leq$ 0.05

ments. The far-red effects may have been masked by increased red wavelengths under higher chamber PPF. This result suggests that a particular proportion of far-red to red photon flux reduces the level of oedema, and afar-red level below a critical proportion has no effect on injury. Additional research is necessary to determine if a higher far-red: red photon flux ratio may inhibit injury. However, higher farred flux may induce excessive stem elongation and make treatment valueless.

The plants treated with far-red at the start of the dark period showed increased stem elongation and double the level of injury compared to the control plants. The elongation may be attributed to the far-red treatment; however, the cause of the elevated level of injury is unknown.

The control of oedema by far-red treatment of ivy geraniums was much less than the con- trol found on Solanaceous sp. In our studies, no treatment reduced gall formation more than $50 \%$, whereas on Solanaceous sp., intumescence injury was inhibited with far-red exposure (Morrow and Tibbitts, 1988). Thus, we conclude that oedema injury has different causal factors on geraniums than on Solanaceous sp. and is regulated by different physiological systems within the separate species of plants. This difference is supported by the fact that UV radiation appears to have little effect on oedema in geraniums, yet effectively prevents injury on Solanaceous sp. (Morrow and Tibbitts, 1988). This lack of UV regulation on geraniums was apparent in the fourth experiment, where oedema developed on all plants, even though plants were being irradiated with UV wavelengths from the unfiltered coolwhite fluorescent lamps. Solanaceous plants, grown under similar levels of UV wavelengths from cool-white fluorescent lamps, did not develop oedema (Morrow andTibbitts, 1988). The possibility that oedema on geraniums has different casual factors than on Solanaceous plants also is indicated by the observation that the symptoms on geraniums develop primarily on mature, fully enlarged leaves, whereas oedema develop primarily on enlarging leaves of Solanaceous sp.

From the results of these experiments, we conclude that installing far-red treatment systems to control oedema on ivy geraniums in a commercial facility would not be beneficial. The plants would need to be treated from the time of planting to the time of sale, and the injury still may not be completely inhibited.
Indication of control appeared probable under low PPF levels; however, in greenhouses where solar PPF fluctuates with season and cloud cover, maintenance of a useful level of far-red flux would be difficult. Also, greenhouse PPF levels generally are higher than those used in the experiments; therefore, applying an adequate amount of far-red flux may induce undesirable stem elongation. Thus, the primary consideration for growers plagued by oedema injury should be selection of cultivars that are resistant to injury and careful management of the production environment to avoid excess watering, high humidity, and high light intensity.

\section{Literature Cited}

Balge, R.J., B.E.Struckmeyer, andG.E. Beck.1969. Occurrence, severity and nature of oedema in Pelargonium hortorum Ait.J.Amer.Soc.Hort. Sci. 94:181-183.

Hammer, P. A., T.W. Tibbitts, R.W. Langhans, and J.C. McFarlane.1978.Base-line growth studies of 'Grand Rapids'lettuce incontrolled environments. J.Amer.Soc.Hort Sci. 103(5):6494555.

Holmes, M.G. and H. Smith. 1977. The function of phytochrome in the natural environment-IV. Lightqualityandplantdevelopment.Photochem. Photobiol. 25:55 1-557.

Metwally, A.W., G.E. Beck, andB.E.Struckmeyer. 1971.Densityandbehaviorofstomataof Pelargonium hortorum Ait grown under three soil moisture regimes. J. Amer. Soc. Hort. Sci. 96(1):31-34

Morrow, R.C. and T.W. Tibbitts. 1988. Evidence for involvement of phytochrome in tumordevelopment on plants. Plant Physiol. 88:1110-1114. 